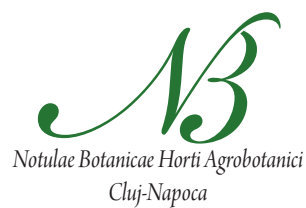

\title{
The Influence of Heavy Metals on Growth and Development of Eichbornia crassipes Species, Cultivated in Contaminated Water
}

\author{
Erzsebet BUTA*, Laura PAULETTE, Tania MIHĂIESCU, Mihai BUTA, Maria CANTOR \\ ${ }^{1}$ University of Agricultural Sciences and Veterinary Medicine, 3-5 Mănăştur Street 400372, Cluj- \\ Napoca,Romania; ebuta2008@yahoo.com (*corresponding author)
}

\begin{abstract}
Many plants are capable of accumulating heavy metals (called hyperacumulators), one of which is the water hyacinth Eichhornia crassipes Mart. The roots of this water plant naturally absorb pollutants, including heavy metals such as $\mathrm{Pb}, \mathrm{Hg}, \mathrm{Zn}, \mathrm{Co}, \mathrm{Cd}$, and $\mathrm{Cu}$ and can be used for wastewater treatment. The aim of this study was to assess the influence of heavy metals on growth and development of water hyacinth and to determinate the uptake capacity of heavy metals of this species. It was evaluated for its effectiveness in reducing pollution potential in wastewater. From the combination of experimental factors 11 variants resulted. The results showed that Eichhornia absorbed a high quantity of $\mathrm{Pb}(504 \mathrm{mg} / \mathrm{kg}$ dry matter $)$ and $\mathrm{Cu}(561 \mathrm{mg} / \mathrm{kg}$ dry matter $)$ in their roots. More $\mathrm{Cu}$ accumulated in the root compared to $\mathrm{Pb}$. The level of $\mathrm{Zn}$ absorption was lower in roots $(84 \mathrm{mg} / \mathrm{kg}$ dry matter) and also in stem plus leaves $(51 \mathrm{mg} / \mathrm{kg} \mathrm{dry}$ matter). A high quantity of Cd (281 mg/kg dry matter) was removed from stem plus leaves of Eichhornia while the level of Co was very low $(45 \mathrm{mg} / \mathrm{kg}$ dry matter). Regarding the growth and development of this plant it was found that in tanks with Pb plants had a better development and had flowers also, and in the case of $\mathrm{Cd}, \mathrm{Co}, \mathrm{Cu}$ at a double dose of maximum admissible limits, the plants died and the growing period was shorter.
\end{abstract}

Keywords: hydrophytes, hyperacumulators, waste water

\section{Introduction}

For growth and development plants absorb large amounts of elements and only small amounts of toxic elements that could harm them. There are 35 metals that concern because of occupational or residential exposure; 23 of these are the heavy elements or "heavy metals": Ag, An, As, $\mathrm{Au}, \mathrm{Bi}, \mathrm{Cd}, \mathrm{Ce}, \mathrm{Cr}, \mathrm{Co}, \mathrm{Cu}, \mathrm{Fe}, \mathrm{Ga}, \mathrm{Hg}, \mathrm{Mn}, \mathrm{Ni}, \mathrm{Pb}$, Pt, Te, Tl, Sn, U, V, and Zn (Glanze, 1996). While many heavy metals have considerable toxicity, others are not deemed to possess significant toxic properties. In fact, several of these elements including $\mathrm{Zn}, \mathrm{Fe}, \mathrm{Cu}, \mathrm{Cr}$ and $\mathrm{Co}$ are necessary for metabolic function for a large class of organisms (Hogan, 2010). Removal of toxic heavy metals from industrial wastewater is essential from the standpoint of environmental pollution control (Hasan et al., 2007).

Aquatic plants absorb heavy metals from the water; and those rooted ones also from the bed material. Generally, aquatic plants accumulate high amounts of heavy metals. In this way, they reflect the toxicity of the water environment and may serve as a tool for the biomonitoring of contaminated waters (Cardwell et al., 2002; Ravera, 2001; Sawidis et al., 1995; Wang, 1991; Zurayk et al., 2001).

Hydrophytes can absorb heavy metals via roots, stems or leaves, and accumulate them in organs. They can absorb elements selectively. Accumulation and distribution of heavy metals in the plant depends on the plant species, bioavailability, $\mathrm{pH}$, cation exchange capacity, dissolved oxygen, temperature, and secretion of roots. Plants are employed in the decontamination of heavy metals from polluted water and have demonstrated high performances in treating mineral water and industrial effluents (Cheng, 2003).

Many aquatic plants have been used as a bio-filter to remove heavy metals from waste water such as: Salvinia sp. (Espinoza-Quinones et al., 2005), Potamogeton crispus (Aysel et al., 2010), Potamogeton pectinatus and Potamogeton malaianus (Peng et al., 2008), Typha angustifolia (Dilek and Ahmet, 2004), Myriophyllum heterophyllum (Aysel et al., 2010), Lemna minor (Yeşim et al., 2003) and Azolla caroliniana (Bennicelli et al., 2004). In addition, Lavid et al. (2000) discovered that water lilies (Nymphaea variety) are endowed with anatomical and physiological traits that allow them to thrive on water with high concentrations of heavy metals such as $\mathrm{Cd}, \mathrm{Hg}, \mathrm{Ni}$ and $\mathrm{Co}$.

Experiments by Alka and Triphati (2007) revealed that Eichbornia crassipes bioaccumulated the most heavy metals followed by Lemna minor and Azolla pinnata. Skinner et al. (2007) evaluated the effectiveness of four aquatic plants including water hyacinth (Eichhornia crassipes), water lettuce (Pistia stratiotes), zebra rush (Scirpus tabernaemontani) and taro (Colocasia esculenta) for their capabilities in removing $\mathrm{Hg}$ from water. They utilised concentrations of $0 \mathrm{mg} / \mathrm{L}, 0.5 \mathrm{mg} / \mathrm{L}$, and $2 \mathrm{mg} / \mathrm{L}$ of $\mathrm{Hg}$ for 30 days. All 
136

species appeared to reduce $\mathrm{Hg}$ concentrations in the water via root uptake and accumulation. Water lettuce and water hyacinth were the most effective, followed by taro and zebra rush.

The National Aeronautics and Space Administration/ National Space Technology Laboratories (NASA/NSTL) have successfully used water hyacinths to remove organics and heavy metals from chemical wastes before their discharge (Wolverton et al., 1977). Biofiltration of the heavy metals ( $\mathrm{Pb}, \mathrm{Zn}, \mathrm{Cu}, \mathrm{Cd}, \mathrm{Co}$ ) has been successfully demonstrated using Eichhornia crassipes plants as biological material (Hasan et al., 2007; Wolverton et al., 1977; Xiaomei et al., 2004). Eichhornia can grow so quickly in nutrient-rich waters, such as in polluted ponds or lakes, that the surface covered by the mats doubles every 4-7 days.

The aim of this study was to assess the mode of action and role of aquatic plants in removing heavy metals from wastewater. During the experiments, some observations were also made concerning the morphological characteristics of the plants, and the chemical compounds were analysed.

\section{Materials and methods}

The experiment was conducted in the greenhouse of the Floriculture Department of the University of Agricultural Sciences and Veterinary Medicine Cluj-Napoca, Romania, in the period 24 March 2009-16 June 2009 i.e. with a duration of 84 days. Eleven plastic tanks of 15 litre capacity were used for the studies with water hyacinth. Two plants of different ages (mature and young plants) were put in each tank. The water was treated with different doses of heavy metals (Tab. 1) while tap water was used in the control tank.

The experiment was conducted at an average temperature $29-31^{\circ} \mathrm{C}$. For chemical analysis the following reagents and apparatus were used: $\mathrm{HNO}_{3}$ extra pure Merck (concentration of 65\%) and $\mathrm{H}_{2} \mathrm{O}_{2}$ (concentration of $30 \%$ ) and to determinate the concentration of heavy metals: Perkin
Tab. 1. Doses of elements used in Eichhornia crassipes experiments

\begin{tabular}{cccc}
\hline $\begin{array}{c}\text { No. of } \\
\text { variants }\end{array}$ & Experimental variants & $\begin{array}{c}\text { Heavy metal } \\
\text { dose }(\mathrm{mg} / \mathrm{L})\end{array}$ & $\begin{array}{c}\text { Flowering } \\
\text { time }\end{array}$ \\
\hline $\mathrm{G}_{1} \mathrm{~V}_{1}$ & Water hyacinth + tap water & - & - \\
\hline $\mathrm{G}_{2} \mathrm{~V}_{1}$ & Water hyacinth $+\mathrm{PbAc}_{2}$ & $0,5^{*}$ & 19 May 2009 \\
$\mathrm{G}_{4} \mathrm{~V}_{1}$ & Water hyacinth $+\mathrm{ZnSO}_{4}$ & 1,0 & - \\
$\mathrm{G}_{6} \mathrm{~V}_{1}$ & Water hyacinth $+\mathrm{CuSO}_{4}$ & 0,2 & - \\
$\mathrm{G}_{8} \mathrm{~V}_{1}$ & Water hyacinth $+\mathrm{Cd} \mathrm{pure}$ & 0,3 & - \\
$\mathrm{G}_{10} \mathrm{~V}_{1}$ & Water hyacinth $+\mathrm{Co}\left(\mathrm{NO}_{3}\right)_{2}$ & 1,0 & - \\
$\mathrm{G}_{3} \mathrm{~V}_{2}$ & Water hyacinth $+\mathrm{PbAc}_{2}$ & $1,0^{* *}$ & 20 May 2009 \\
$\mathrm{G}_{5} \mathrm{~V}_{2}$ & Water hyacinth $+\mathrm{ZnSO}$ & 2,0 & - \\
$\mathrm{G}_{7} \mathrm{~V}_{2}$ & Water hyacinth $+\mathrm{CuSO}_{4}$ & 0,4 & - \\
$\mathrm{G}_{9} \mathrm{~V}_{2}$ & Water hyacinth $+\mathrm{Cd} \mathrm{pure}$ & 0,6 & - \\
$\mathrm{G}_{11} \mathrm{~V}_{2}$ & Water hyacinth $+\mathrm{Co}\left(\mathrm{NO}_{3}\right)_{2}$ & 2,0 & - \\
\hline
\end{tabular}

Maximum admissible limits-MAL, ${ }^{* *} 2$ x MAL-double dose (HG188/2002, NTPA-002/2002); Doses exceeding the maximum admissible limits can be toxic to living organisms

Elmer Analyst 800 Spectrometer, Breghof MWS-2 Mineralisation Oven and Direct Q UV3 Water Purify System.

After harvesting, the plants were divided into two parts: stem plus leaves and roots. Each part was dried for 72 hours at $105^{\circ} \mathrm{C}$. All parts were ground and screened by using a sieve of $250 \mu \mathrm{m}$. For each analysed sample $0.03 \mathrm{~g}$ material was used.

\section{Results and discussion}

Some data concerning the morphological characters of plants (root length, diameter of leaves rosette, number of leaves, total weight of water hyacinth) used in research were recorded. The root length $(\mathrm{cm})$ recorded at 24 May (start of experiment) and 16 June (end of experiment) is shown in Fig. 1.

Each solution determines a normal growth of root system. The root length increased with increasing metal concentration. Some studies emphasise that at higher con-

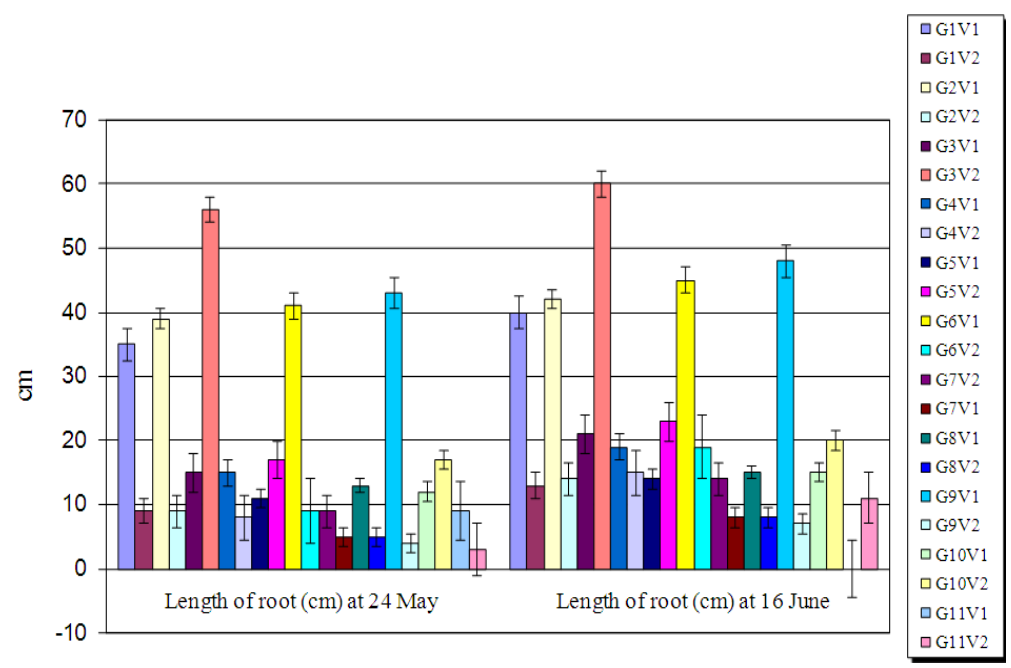

Fig. 1. The root length of Eichhornia crassipes at the start and end of the experiment 


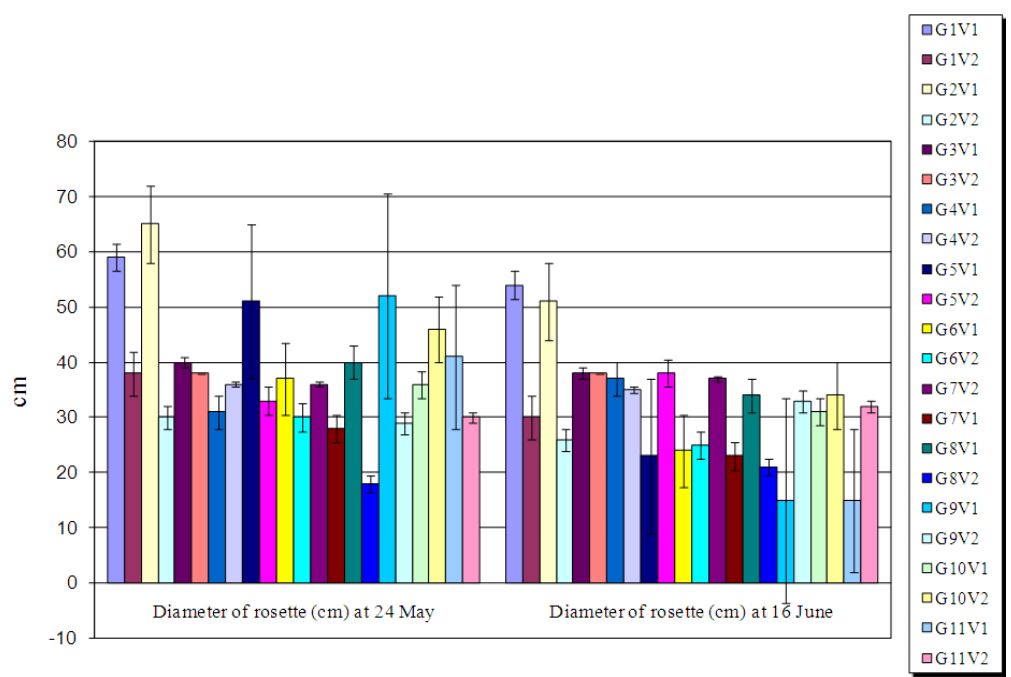

Fig. 2. The diameter of the rosettes of Eichhornia crassipes at 24 May and 16 June

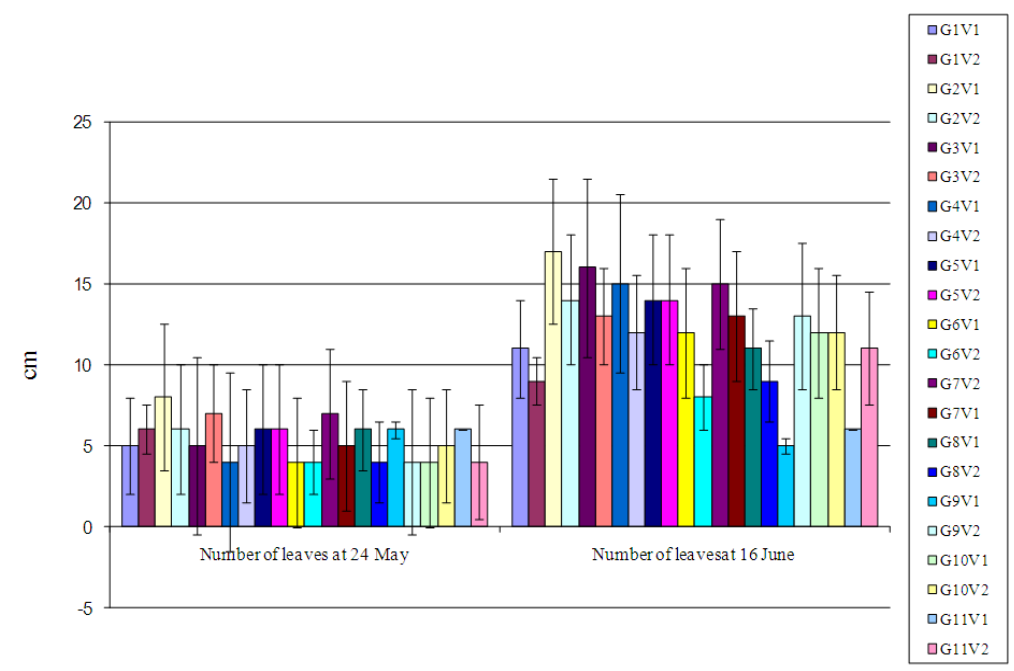

Fig. 3. The number of leaves of Eichhornia crassipes at the start and end of the experiment

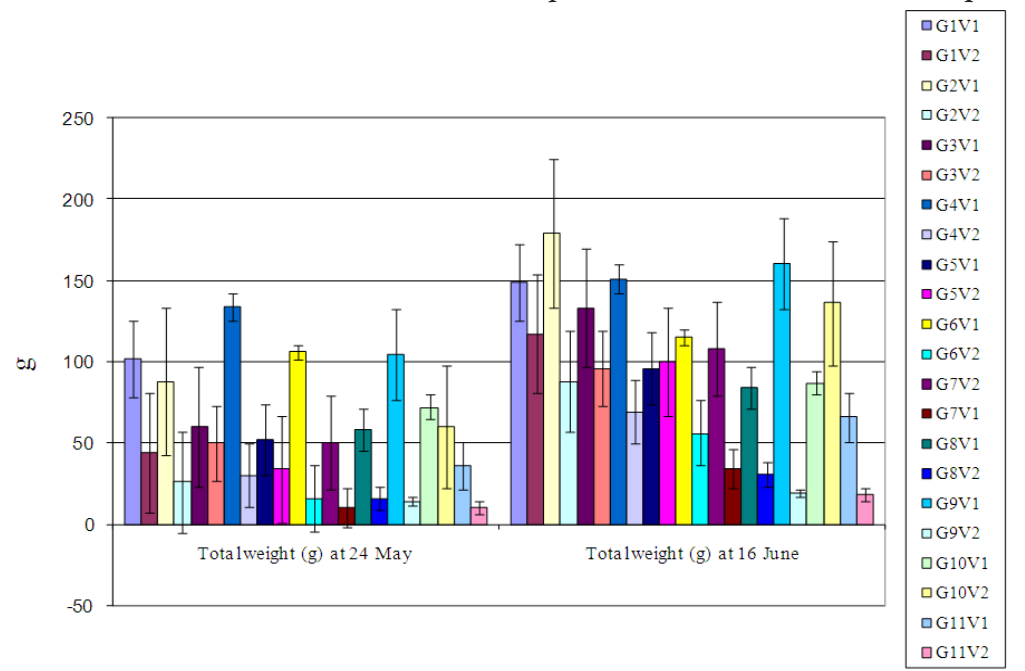

Fig. 4. The total weight of water hyacinth under heavy metal toxicity in Eichbornia crassipes experiments

centrations the metals inhibit plant growth (Hasan et al., 2007).

Regarding the diameter of the rosettes it has been noted that in some cases this character decreases with the increase of metal concentration (Fig. 2). The diameter of 


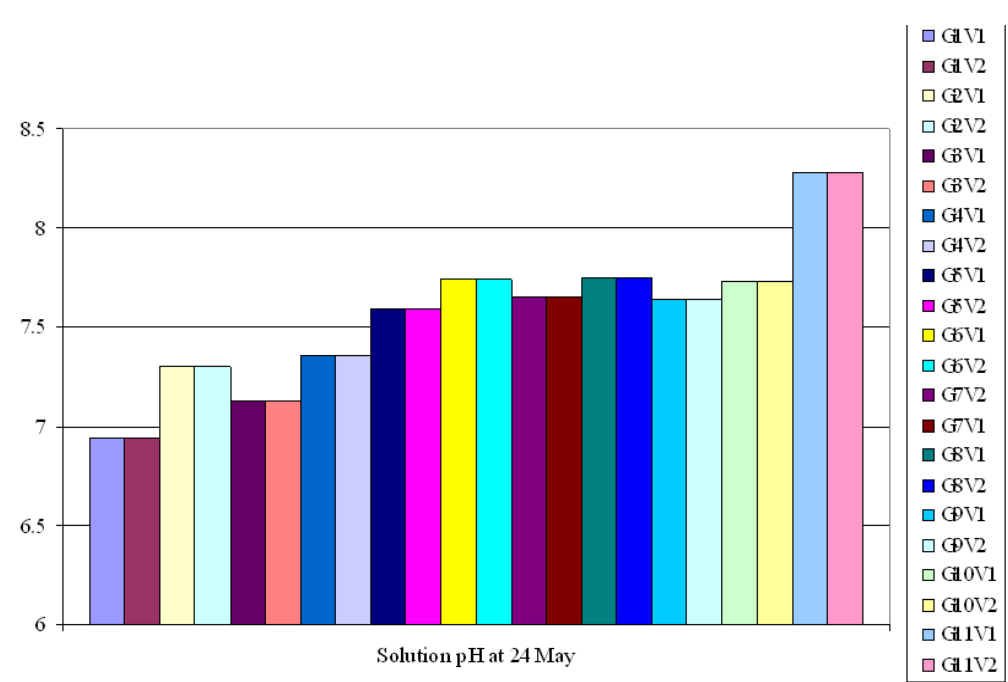

Fig. 5.The effect of metal concentration on solution $\mathrm{pH}$ in Eichhornia crassipes experiments

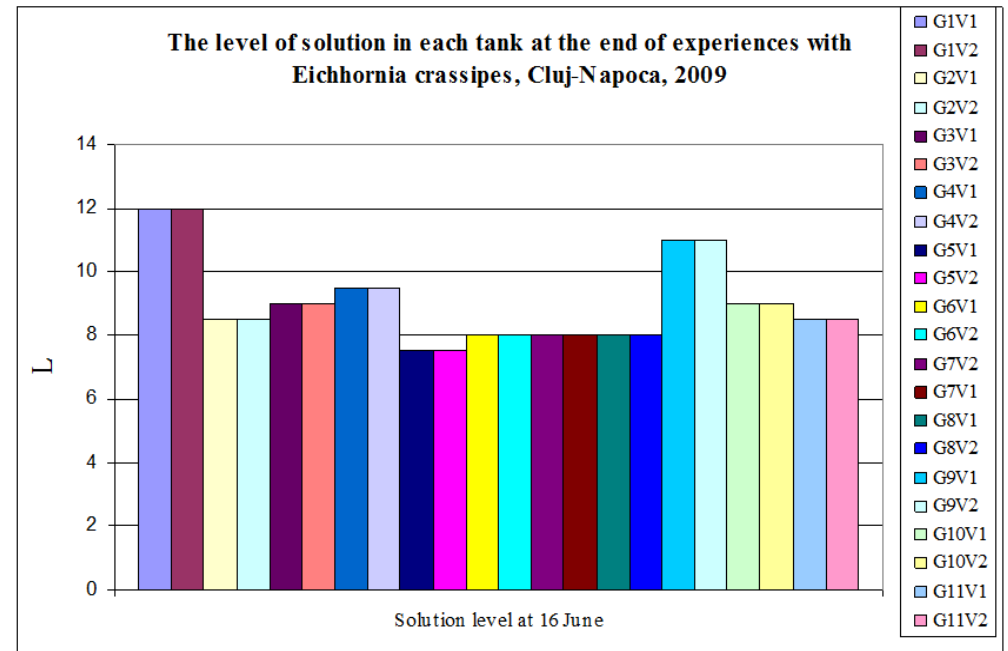

Fig. 6. The level of solution at the end of the experiments in the case of water hyacinth

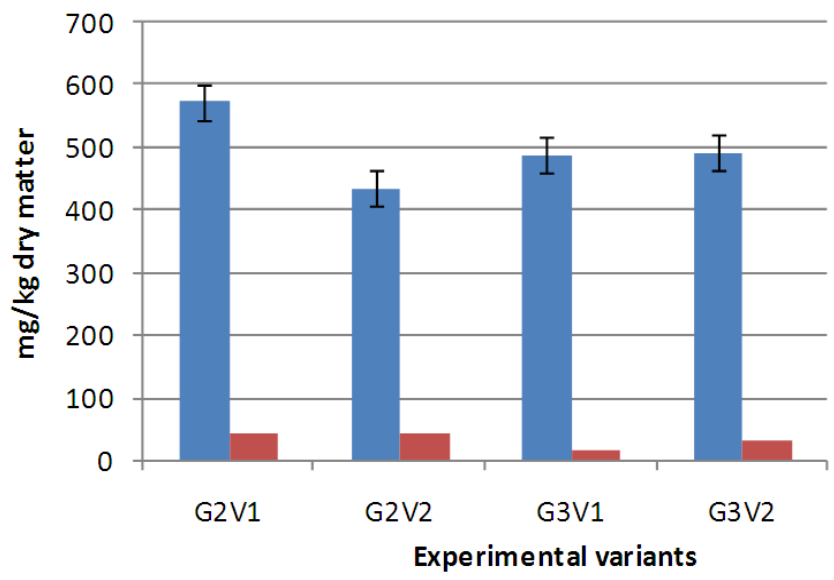

a $\mathrm{Pb}$ quantity in root $(\mathrm{mg} / \mathrm{kg}$ dry matter)

- Pb quantity in stem+leaves (mg/kg dry matter)

Fig. 7. Lead quantity in all part of plants, in Eichhornia crassipes experiments

the end of the experiment the data show that all the plants developed a large number of leaves (Fig. 3). There was a positive correlation between the level of metal concentration and the analysed character.
The effect of metal concentration on the total weight rate of the water hyacinth is shown in Fig. 4. It appears that the total weight rate increased with an increase in metal concentration. 


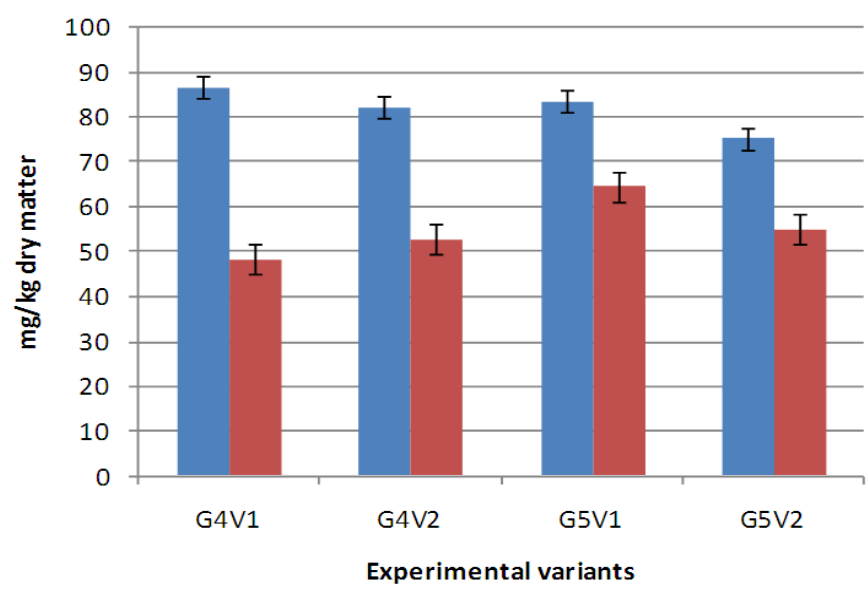

- Zn quantity in root $(\mathrm{mg} / \mathrm{kg}$ dry matter)

- Zn quantity in stem+leaves ( $\mathrm{mg} / \mathrm{kg}$ dry matter)

Fig. 8. Zinc level in plants, in experiments with Eichhornia crassipes

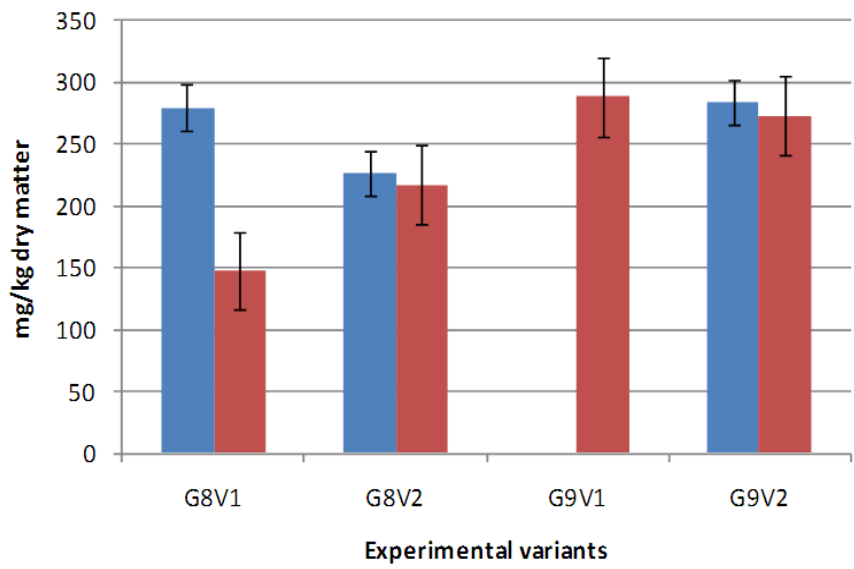

- Cd quantity in root $(\mathrm{mg} / \mathrm{kg}$ dry matter)

Cd quantity in stem+leaves $(\mathrm{mg} / \mathrm{kg}$ dry matter)

Fig. 9. Uptake of Cd by water hyacinth in Eichhornia crassipes experiments

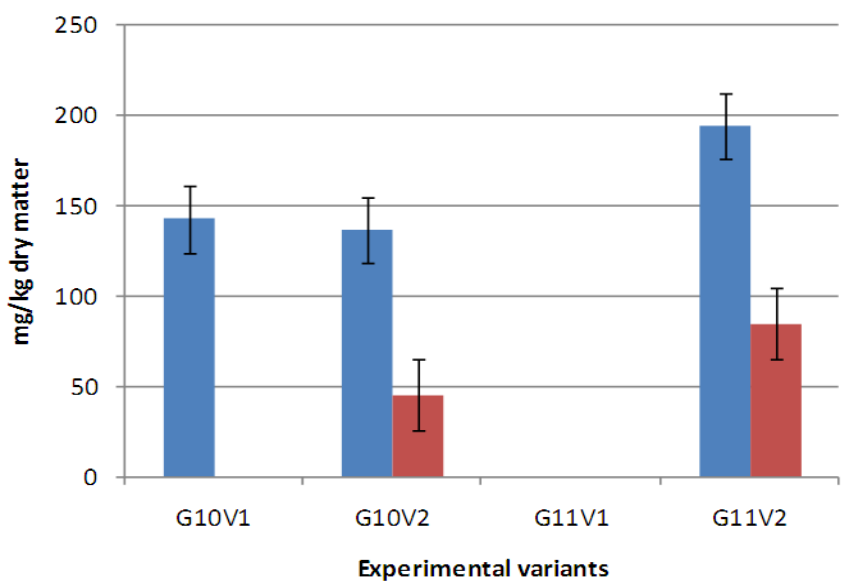

- Co quantity in root $(\mathrm{mg} / \mathrm{kg}$ dry matter)

- Co quantity in stem+leaves $(\mathrm{mg} / \mathrm{kg}$ dry matter)

Fig. 10. Cobalt level in all parts of water hyacinth

After establishing the heavy metal concentration in experimental tanks, the level of $\mathrm{pH}$ was determined, which varied between 6.94-8.28 (Fig. 5). The results show that upon the addition of heavy metal the solution $\mathrm{pH}$ was greatly modified. The lowest value was measured in the control (tap water) and the highest value was recorded at $\mathrm{Co}\left(\mathrm{NO}_{3}\right)_{2}$ double dose. In each case, the solution was alkaline; no one concentration caused the acidity of the developing medium.
The level of solution in the tank at the end of the culture is shown in Fig. 6. In each tank, the level of solution decreased during the period of plant development. The lowest consumption was registered in the case of normal water. The highest one was measured in the solution with a double dose of $\mathrm{ZnSO}_{4}$, the other experimental variants showed approximately the same values.

Eichhornia crassipes uptake capacity of $\mathrm{Pb}, \mathrm{Zn}, \mathrm{Cu}$, $\mathrm{Cd}$, and Co was studied. The plant tissue analysis made by 


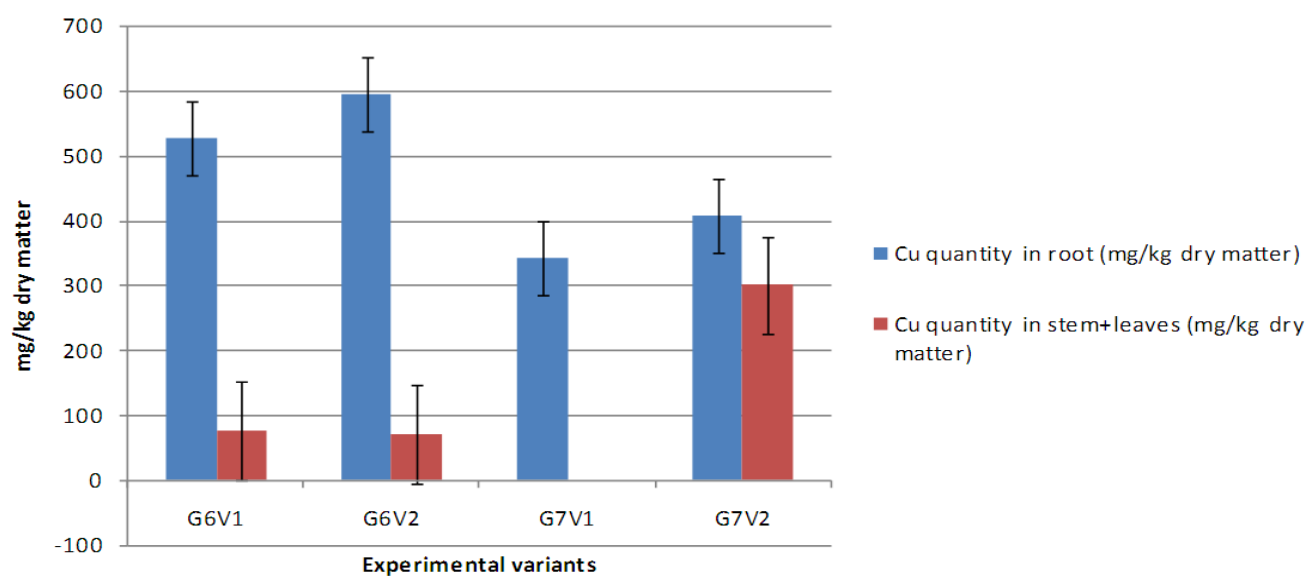

Fig. 11. Copper absorption in different parts of Eichhornia crassipes in experiments

Alka and Triphati (2007) revealed a higher accumulation of metals in roots than leaves of water hyacinth. It is known that lead in high concentrations is a potential health risk, especially around large cities or industrial areas.

The $\mathrm{Pb}$ uptake in the roots of water hyacinth was higher than in the stem plus leaves. The accumulation of $\mathrm{Pb}$ is higher in the case of a single dose (Fig. 7). The accumulation of this metal in the roots is sufficiently high such that Eichhornia crassipes is recommended for filtration of wastewater.

In the stem plus leaves the translocation was lower than roots. The data in Fig. 7 show that the accumulation rate in plants decreased with increasing concentration. The double dose negatively influenced the process of metal absorption in stem plus leaves.

Zinc is an essential and beneficial element for human bodies and plants. Complete exclusion of $\mathrm{Zn}$ is not possible due to its dual role, an essential microelement on the one hand and a toxic environmental factor on the other (Xiaomei et al., 2004). Zinc is considered with cadmium to be a very mobile and bioaccessible metal, which through its accumulation in soils and plants can reach the food chain.

In the experiment of Delgado et al. (1993) concerning the phytotoxic effect and uptake of cadmium, chromium and zinc by water hyacinth, plants showed some necrosis at higher concentration of solutions. Among the three elements tested, $\mathrm{Cd}$ was the most toxic. The greater absorption was registered at $\mathrm{Cr}$ better than $\mathrm{Zn}$ and $\mathrm{Cd}$.

In the experiments with water hyacinth higher quantities of $\mathrm{Zn}$ were measured in roots at single and double dose, too (Fig. 8). Approximately the same values of this metal were recorded in the stem plus leaves as in roots without any necrosis.

In addition to direct absorption by roots, cadmium can be absorbed through leaves and translocated in the plant, which is a significant route of access to this element in food and their consumption level implicit by the human body.

The accumulation of cadmium in analysed material is expressed as $\mathrm{mg} / \mathrm{kg}$ dry matter. The data for accumulation of $\mathrm{Cd}$ are presented in Fig. 9, both for the roots and stem plus leaves. In the roots the higher $\mathrm{Cd}$ level was recorded in the case of increasing concentration (double dose). Also in the stem plus leaves this metal shows increases at double dose. The uptake at single dose was $182.99 \mathrm{mg} / \mathrm{kg}$ dry matter and in the case of double dose was $280.85 \mathrm{mg} / \mathrm{kg}$ dry matter (Fig. 9).

The uptake of the metals by the plant and its tissues are affected by several parameters: $\mathrm{pH}$, temperature, evaporation, solar radiation, chemical compounds of normal water and others. It has been taken only two parameters: solution $\mathrm{pH}$ and heavy metal concentration.

Regarding the cobalt translocation in all part of Eichhornia crassipes Mart. it can be conclude that this metal is present in higher quantities in the roots when it has been used a single dose. This means that with increasing metal concentration the absorption tends to decrease (Fig. 10).

Analysing the quantity of heavy metal in stem plus leaves, the uptake is increasing with an increasing metal concentration (double dose).

Copper sulphate (CuSO4) is used as a fungicide and as algae control in domestic lakes and ponds. It is used in gardening powders and sprays to kill mildew. Copper ions are highly toxic to fish, so care must be taken with the dosage. The very low concentrations of copper sulphate used to control most species of algae also inhibit growth of bacteria such as Escherichia coli. Copper is particularly adsorbed or fixed in the soil, making it one of the less displaceable heavy elements.

The results from Fig. 11 show that the Cu quantity was higher in roots than in stem plus leaves. The maximum translocation was registered when a low concentration of this metal (single dose) was used. A negative correlation was found between translocation and increasing concentration. In the other parts of Eichhornia (stem plus leaves) the absorption was lower than in the roots.

In Fig. 9-11 some data are missing, because using double dose of $\mathrm{Cd}, \mathrm{Co}$ and $\mathrm{Cu}$ the plants died and the remaining biological material was insufficient to make the analy- 
sis. In the tanks with $\mathrm{Pb}$ contamination plants had a better development and had flowers also.

\section{Conclusions}

Analysing the data recorded in the greenhouse belonging to UASVM Cluj-Napoca, using Eichhornia crassipes to take up heavy metals from water, it can be conclude that Eichhornia absorbed high quantities of $\mathrm{Pb}$ and $\mathrm{Cu}$ in the roots. Comparatively more $\mathrm{Cu}$ was accumulated in the roots compared to $\mathrm{Pb}$. For $\mathrm{Zn}$ it was observed that the absorption was lower in roots and in stem plus leaves also. Eichhornia stem plus leaves can remove a high quantity of $\mathrm{Cd}$ and a very low amount of Co. Water hyacinth can be used as a "bio-filter" to prevent the spread of heavy metal contamination in the aquatic environment and successfully used for the removal of $\mathrm{Pb}, \mathrm{Zn}, \mathrm{Cd}, \mathrm{Co}$ and $\mathrm{Cu}$. In tanks with $\mathrm{Cd}$, $\mathrm{Co}$ and $\mathrm{Cu}$ during the growing season was shorter than the contaminated tanks with $\mathrm{Pb}$ and $\mathrm{Zn}$. It was found that the absorbtion period of plants is different depending on the type of metal and dosage used.

\section{References}

Alka RU, Tripathi BD (2007). Principle and process of biofiltration of $\mathrm{CD}, \mathrm{Cr}, \mathrm{Co}, \mathrm{Ni}$ and $\mathrm{Pb}$ from tropical opencast colamine effluent. J Water Air Soil Poll 180:213-223.

Aysel S, Elmas E, Gümüş F, Ridvan ES (2010). Removal of cadmium by Myriophyllum heterophyllum Michx. and Potamogeton crispus L. and its effect on pigments and total phenolic compounds. J Archives Environ Contam Toxicol 54(4):612-618.

Bennicelli R, Pniewska ZS, Banach A, Szajnocha K, Ostrowski J (2004). The ability of Azolla caroliniana to remove heavy metals (Hg (II), Cr (III), Cr (VI)) from municipal waste water. J Chemosphere 55(1):141-146.

Cardwell AJ, Hawker DW, Greenway M (2002). Metal accumulation in aquatic macrophytes from southeast Queensland, Australia. J Chemosphere 48:653-663.

Cheng $S$ (2003). Heavy metals in plants and phytoremediation. J Environ Poll Res Int 10(5):335-340.

Delgado M, Bigeriego M, Guardiola E (1993). Uptake of Zn, Cr and Cd by water hyacinths. J Wat Res 27(2):269-272.

Dilek DR, Aksoy A (2004). Accumulation of heavy metals in Typha angustifolia (L.) and Potamogeton pectinatus (L.) living in Sultan Marsh (Kayseri, Turkey). J Chemosphere 56(7):685-696.

Espinoza-Quinones FR, Zacarkim CE, Palacio SM, Obregon CL, Zenatti DC, Galante RM, Rossi N, Rossi FL, Pereira
IRA, Welter RA (2005). Removal of heavy metal from polluted river water using aquatic macrophytes Salvinia sp. Brazilian J Physics 35(3B):744-746.

Glanze WD (1996). Mosby Medical Encyclopedia, Revised Edition 1996. St. Louis MO: C.V. Mosby.

Hasan SH, Talat M, Rai S (2007). Sorption of cadmium and zinc from aqueous solution by water hyacinth (Eichchornia crassipes). Biores Technol 98:918-928.

HG 188/2002 (2002). The $2^{\text {nd }}$ Appendix. Standard regarding evacuation of wastewater into sewages and water treatment stations, NTPA-002/2002.

Hogan CM (2010). Heavy metal. Encyclopedia of Earth. National Council for Science and the Environment. Monosson E, Cleveland C (Eds.). Washington DC.

Lavid N, Barkay Z, Tel-Or E (2000). Accumulation of heavy metals in epidermal glands of the waterlily (Nymphaeceae). Planta J 212:313-322.

Peng K, Luo C, Lou L, Li X, Shen Z (2008). Bioaccumulation of heavy metals by the aquatic plants Potamogeton pectinatus L. and Potamogeton malaianus Miq. and their potential use for contamination indicators in wastewater treatment. Sci Total Environ 392(1):22-29.

Ravera O (2001). Monitoring of the aquatic environment by species accumulator of pollutants: a review. In: Ravera $\mathrm{O}$ (Ed.). Scientific and legal aspects of biological monitoring in freshwater. J Limnol 60(1):63-78.

Sawidis T, Chett MK, Zachariadis GA, Stratis JA (1995). Heavy metals in aquatic plants and sediments from water systems in Macedonia, Greece. J Ecotoxicol Environ Saf 32:73-80.

Skinner K, Wright N, Porter-Goff E (2007). Mercury uptake and accumulation by four species of aquatic plants. J Environ Poll 145(1):234-237.

Wang W (1991). Literature review on higher plants for toxicity testing. J Water Air Soil Poll 59:381-400.

Wolverton BC, McDonald RC, Rebeca C (1977). Wastewater treatment utilizing water hyacinths. In: Pro. Nam. Conf. on Treatment and Disposal of Industrial Wastewaters and Residue 14:205-208.

Zurayk R, Sukkariyah B, Baalbaki R (2001). Common hydrophytes as bioindicators of nickel, chromium and cadmium pollution. J Water Air Soil Poll 127:373-388.

Xiaomei L, Kruatrachue M, Pokethitiyook P, Homyokb K (2004). Removal of cadmium and zinc by water hyacinth, Eichhornia crassipes. J Sci Asia 30:93-103.

Yeşim K, Davut B, Izzet K, Ali Z, Hasan G (2003). Bioaccumulation of nickel by aquatic macrophyta Lemna minor (Duckweed). J Agricult Biol 3:281-283. 